\title{
KARAKTERISTIK OSEANOGRAFI LAUT BANDA BAGIAN BARAT PADA MUSIM BARAT DARI DATA PENGUKURAN IN-SITU 2016
}

\section{OCEANOGRAPHYC CHARACTERISTICS OF WEST BANDA SEA IN WEST SEASON USING IN-SITU MEASUREMENT DATA 2016}

\author{
Khairul Amri, Asep Ma'mun dan Muhammad Taufik \\ Balai Riset Perikanan Laut (BRPL) \\ Komplek Raiser Cibinong KM. 47 Nanggewer Mekar, Cibinong-Bogor \\ Email: khairulamriuyu@gmail.com
}

(Diterima: 13 Februari 2021; Diterima setelah perbaikan: 15 September 2021; Disetujui: 19 September 2021)

\begin{abstract}
ABSTRAK
Perairan Laut Banda bagian barat merupakan lokasi fishing ground potensial nelayan yang berpangkalan di Kendari dan sekitarnya. Karakteristik oseanografi perairan ini penting diketahui, terutama pada muson barat, karena masih sedikit data hasil kajian berbasis pengukuran in-situ. Penelitian ini dilaksanakan pada 4-17 Februari 2016 (akhir musim barat) dengan cruise kapal riset KR. Baruna Jaya VII-LIPI. Sampling dilakukan pada 19 stasiun oseanografi menggunakan Conductivity Temperature Depth (CTD) SBE 911 plus untuk mengukur suhu, konduktivitas, tekanan, fluorometer, turbiditas, transmisi cahaya dan oksigen terlarut (DO). Pengukuran arus permukaan menggunakan current meter type AEM-USB JFE Advantech. Pengolahan data CTD dilakukan dengan software SBE Data Processing dan analisa serta visualisasi data dilakukan menggunakan software Ocean data View (ODV). Hasil menunjukkan, secara vertikal kedalaman lapisan tercampur (mixed layer) berada sampai kedalaman $70 \mathrm{~m}$. Fluktuasi terbesar suhu berada pada kedalaman $125 \mathrm{~m}$ sebesar $20.40{ }^{\circ} \mathrm{C}$ dengan simpangan baku $1.085{ }^{\circ} \mathrm{C}$, menunjukkan lapisan termoklin berada cukup dalam. Parameter salinitas, menunjukkan fluktuasi terbesarnya berada di kedalaman $50 \mathrm{~m}$ (rerata 34.27 psu dan simpangan baku 0.578 psu). Dari lapisan termoklin hingga $500 \mathrm{~m}$ tidak ditemukan ciri massa air bersalinitas tinggi yang berasal dari Pasifik Utara/Selatan. Kandungan oksigen maksimum berada pada isopiknal $<5$. Kandungan klorofil maksimum umumnya berada di sekitar isopycnal 22. Secara horizontal, nilai sebaran suhu permukaan laut (SPL) rata-rata $29.64{ }^{\circ} \mathrm{C}$ dengan pola nilai sebaran yang semakin tinggi ke arah daratan. Rata-rata salinitas permukaan 33.58 psu dengan pola makin tinggi ke arah tengah perairan. Nilai sebaran rata-rata kandungan oksigen terlarut (DO) sebesar $6.88 \mathrm{mg} / \mathrm{l}$. Kecepatan arus permukaan berkisar $0.4-0.8 \mathrm{~m} /$ detik cenderung bergerak ke arah selatan, kecuali di stasiun bagian selatan Kepulauan Wakatobi arus menuju utara, terkait masih adanya pengaruh dorongan massa air dari Laut Flores. Nilai sebaran klorofil permukaan rata-rata $0.13 \mathrm{mg} / \mathrm{m}^{3}$ lebih rendah dibandingkan nilai rerata di perairan Indonesia pada musim barat. Pada akhir musim barat ini, tidak ditemukan adanya indikasi upwelling.
\end{abstract}

KATA KUNCI: Laut Banda; karakteristik oseanografi; pengukuran in-situ; musim barat

\begin{abstract}
The Western part of the Banda Sea is a potential fishing ground location for fishermen based in Kendari and its surroundings. It is essential to understand the oceanographic features of these waters, especially in the Western Monsoon, because there is still little data from the study results based on in-situ measurements. This research was conducted on 4-17 February 2016 (end of the west season) using RV. Baruna Jaya VII-LIPI research vessel. Sampling was carried out at 19 stations using the SBE 911 Plus Conductivity Temperature Depth (CTD) to measure oceanographical parameters such as temperature, conductivity, pressure, fluorometer, turbidity, light transmission and dissolved oxygen (DO). Surface current measurement using
\end{abstract}

\# Korespondensi: Balai Riset Perikanan Laut

E-mail: khairulamriuyu@gmail.com 
the JFE Advantech AEM-USB type Current meter: SBE Data Processing software was used to process CTD data while the Ocean Data View (ODV) is for analysis and visualization. The results show, vertically, the depth of the mixed layer is up to a depth of $70 \mathrm{~m}$. The considerable temperature fluctuation is at a depth of $125 \mathrm{~m}$ at $20.40{ }^{\circ} \mathrm{C}$ with a standard deviation of $1.085{ }^{\circ} \mathrm{C}$, indicating that the thermocline layer is quite deep. The salinity parameter shows that the largest fluctuation is at a depth of $50 \mathrm{~m}$ (mean 34.27 psu with standard deviation of $0.578 \mathrm{psu}$ ). From the thermocline layer up to $500 \mathrm{~m}$, there was no sign of high salinity water masses originating from the North / South Pacific. The maximum oxygen content is at isopycnal $<5$. The highest range of chlorophyll is generally around isopycnal 22. Horizontally, the average sea surface temperature (SPL) value is $29.64^{\circ} \mathrm{C}$ with a pattern of distribution values that are getting higher towards the land. The average surface salinity is 33.58 psu with a higher pattern towards the middle of the water: The average amount of surface chlorophyll distribution is $0.13 \mathrm{mg} / \mathrm{m}^{3}$, with the highest value being in the middle of the water. The average distribution value of dissolved oxygen (DO) is $6.88 \mathrm{mg} / \mathrm{l}$. Surface current velocities ranging from $0.4-0.8 \mathrm{~m} / \mathrm{sec}$ tend to move to the south, except at the southern station of the Wakatobi Islands, the currents are towards the north, due to the influence of water mass forces from the Flores Sea. At the end of this west season, there was no indication of upwelling.

KEYWORDS: Banda Sea; oceanographical features, in-situ measurement; west season

\section{PENDAHULUAN}

Wilayah Pengelolaan Perikanan (WPP) 714 Laut Banda merupakan perairan dengan topografi dasar laut yang sangat kompleks dan massa airnya merupakan kombinasi massa air perairan oseanik (laut dalam) di bagian timur, sementara di bagian barat merupakan perairan yang lebih dangkal dengan beberapa kepulauan serta terumbu karang. Suyarso (1999) menyebutkan, bagian barat perairan ini berbentuk basin (cekungan) dan bagian timur berbentuk palung. Bagian barat Laut Banda yang lebih dangkal meliputi perairan Teluk Tolo, perairan Taliabo, perairan Wakatobi serta perairan Kendari dan kepulauan sekitarnya (Pulau Wowoni, Saponda, Menui dan Umbele).

Massa air Laut Banda mendapat pengaruh langsung dari aliran massa air Samudera Pasifik melalui Indonesian Troughflow (ITF) atau ARLINDO (Arus Lintas Indonesia), yang menurut (Gordon, 1986) merupakan bagian dari aliran air hangat antar samudera ("global scale oceanic belt"). Bentuk topografi Laut Banda yang kompleks sangat menentukan dalam pengendalian pertukaran massa air. Dari beberapa penelitian sejak tahun 1930 yaitu penelitian Snellius dan Lembaga Ilmu Pengetahuan Indonesia (LIPI) tahun 1950 menyimpulkan bahwa perairan ini berfungsi seperti jantung perairan Indonesia (Wyrtki 1958; 1961). Perairan ini merupakan satu-satunya laut yang semi tertutup di wilayah ekuator (Sulaiman, 2000).

Pada periode bertiupnya angin muson barat (Desember-Februari) di Laut Banda terjadi penurunan masa air (downwelling) akibat dominansi masukan massa air dari Laut Jawa dan Laut Flores, dan sedikitnya massa air yang mengalir ke Samudera Pasifik menyebabkan terjadi penumpukan massa air pada lokasi tertentu. Sebaliknya, pada periode bertiupnya angin muson timur (Juni-Agustus) terjadi penaikan massa air (upwelling). Prosesnya berlangsung ketika dominannya pergerakan massa air ke arah Laut Flores dan Laut Jawa, sementara massa air yang masuk dari Samudera Pasifik tidak mencukupi, sehingga kekosongan massa air di lapisan permukaan Laut Banda diisi oleh massa air dari lapisan bawah yang bergerak ke atas (Wyrtki 1958, 1961, Birowo, 1984). Dari kajian-kajian yang dilakukan, diamati bahwa kondisi hidrologi Laut Banda sangat spesifik karena adanya pengaruh musim tersebut (Tapilatu, 2016).

Perairan bagian barat Laut Banda yang banyak terdapat pulau-pulau kecil dan spot-spot terumbu karangnya, merupakan lokasi fishing ground potensial nelayan yang berpangkalan di Kendari dan sekitarnya (Hariati et al., 2010). Sampai saat ini belum banyak referensi yang membahas aspek oseanografi perairan bagian barat Laut Banda ini, khususnya kajian yang berbasis dari data oseanografi hasil pengukuran insitu. Beberapa literatur yang tersedia umumnya berbasis analisa data satelit. Oleh karena itu tulisan ini bertujuan memperkaya informasi karakteristik oseanografi perairan Laut Banda bagian barat, berdasarkan data pengukuran in-situ pada bulan Februari 2016 (musim barat).

\section{BAHAN DAN METODE}

\section{Waktu dan Lokasi}

Penelitian dilaksanakan pada 4-17 Februari 2016 (musim barat) dengan cruise (pelayaran) kapal riset KR. Baruna Jaya VII-LIPI. Pengambilan dan pengukuran sampel air laut dilakukan pada 19 stasiun oseanografi (Gambar 1). 


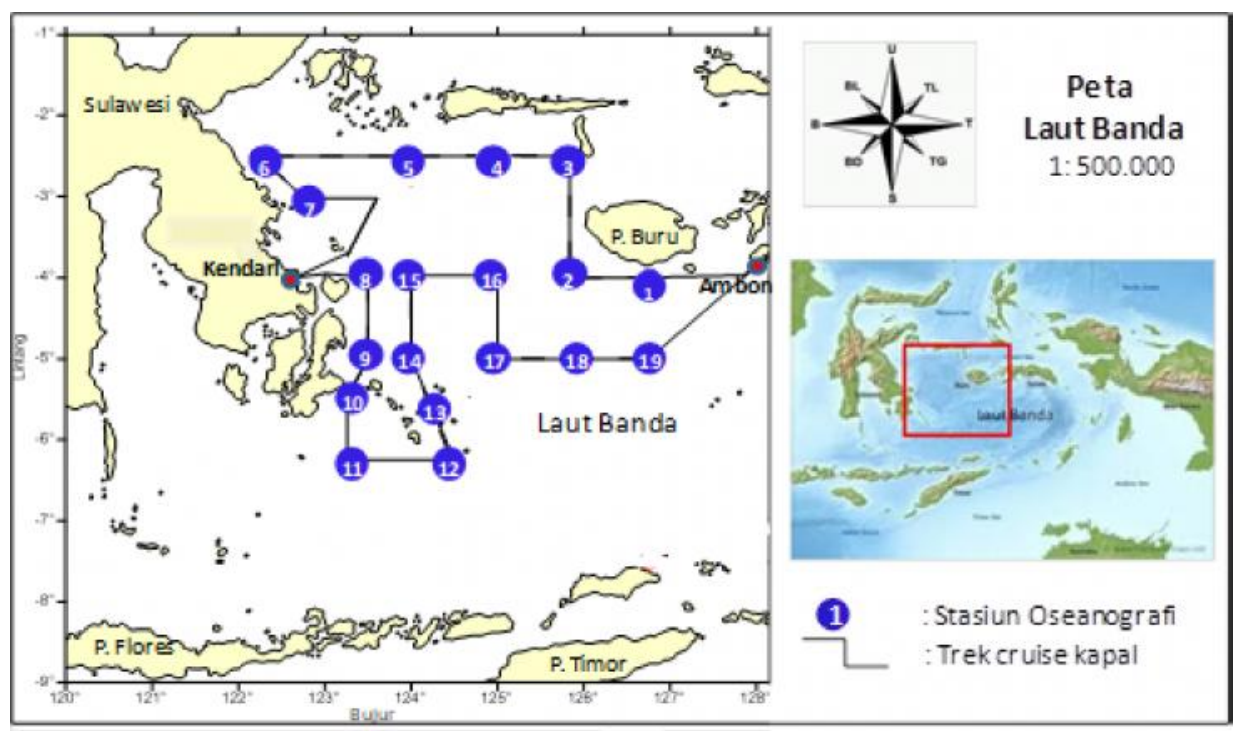

Gambar 1. Lokasi penelitian dan posisi stasiun pengukuran oseanografi di Laut Banda bagian Barat.

Figure 1. Research location and position of oceanographic measurement station in the western Banda Sea.

\section{Alat dan Bahan}

Pengukuran parameter oseanografi menggunakan instrument Conductivity Temperature Depth (CTD) SBE 911 plus. Sistem CTD terdiri dari unit sensor (suhu, konduktivitas, tekanan, fluorometer, turbiditas, transmisi cahaya, oksigen terlarut), unit deck (frame CTD, 12 rosette bottle, trigger tutup rosette, winch, carousel) dan unit komputer. Untuk mengukur arus permukaan menggunakan Current meter type AEMUSB produk JFE Advantech.

\section{Perolehan Data}

Pengukuran suhu, salinitas, oksigen terlarut (Dissolved Oxygen, DO), dan klorofil diperoleh dengan pengoperasian CTD yang diturunkan pada semua stasiun sampai kedalaman $500 \mathrm{~m}$. Pencatatan data CTD secara real time, yang dikontrol oleh deck unit dan seorang operator, data otomatis tersimpan dalam computer untuk digunakan dalam analisis selanjutnya. Interval data oseanografi yang dicatat oleh CTD adalah 1/1 meter. Pengukuran arus dengan current meter dilakukan pada semua stasiun. Pengukuran arus dilakukan pada kedalaman laut sekitar 5 meter dengan interval perekaman setiap 1 detik selama kurang lebih 30 menit. Pengukuran arus permukaan ditujukan untuk mengetahui pola arus permukaan secara horizontal.

\section{Pengolahan dan Analisa Data}

Pengolahan data CTD dilakukan dengan software SBE Data Processing. Langkah pertama pengolahan data dimulai dengan konversi file format .HEX menjadi file text.CNV. Kemudian dilakukan low-pass filter untuk membuang noise dan penghalusan (smoothing) data.
Setelah align, cell thermal, dan loop edit, maka langkah pengolahan data CTD adalah merata-ratakan data (bin average) dengan setting rataan setiap $1 \mathrm{~m}$.

Analisis dan visualisasi data CTD dilakukan dengan software Ocean data View (ODV), mencakup deskripsi statistik data, kalkulasi parameter turunan (densitas air laut, Brunt-Vaisala frequency, gradient suhu potensial, gradient densitas, dst.), penampang melintang (cross-section) data CTD di sepanjang lintasan survei antara kedalaman permukaan sampai $300 \mathrm{~m}$, profil data CTD untuk beberapa stasiun terpilih, dan peta 2 dimensi untuk isosurface plot dari data CTD untuk level kedalaman 10, 25, 50, 75, 100, 150, $200 \mathrm{~m}$. Data yang diperoleh dari current meter diolah dengan menggunakan perangkat lunak WRPLOT View dan Surfer 10. Kondisi lingkungan perairan tersebut di-overlay dengan menggunakan software Surfer ver.10. Selanjutnya dilakukan analisis secara deskriptif untuk mengetahui fenomena oseanografi perairan.

\section{HASIL DAN BAHASAN}

\section{Stastistik Parameter Oseanografi}

Deskripsi statistik (Tabel 1) menunjukkan kedalaman lapisan tercampur di sebagian besar stasiun pengukuran posisinya lebih dalam $>50 \mathrm{~m}$, dan pusat lapisan termoklin berada di kedalaman $125 \mathrm{~m}$. Rerata kedalaman batas bawah lapisan tercampur (mixed layer) yang ditandai garis isoterm $27.5^{\circ} \mathrm{C}$ di kedalaman 70 m. Prasetyo et al, (2018) menyebutkan kedalaman lapisan termoklin Laut Banda rata-rata berkisar antara $110-140 \mathrm{~m}$. 
Rerata suhu lapisan permukaan $(5 \mathrm{~m})$ dan kedalaman $50 \mathrm{~m}$ tidak berbeda jauh, mengindikasikan lapisan termoklin baru mulai terdapat setelah kedalaman $50 \mathrm{~m}$. Fluktuasi terbesar suhu berada pada kedalaman $125 \mathrm{~m}$ sebesar $20.40^{\circ} \mathrm{C}$ dengan simpangan baku $1.085{ }^{\circ} \mathrm{C}$. Lapisan termoklin Laut Banda diidentifikasikan sebagai lapisan isoterm $21^{\circ} \mathrm{C}$ (Bray et al. 1996; Gordon et al. 2000). Hal ini menunjukkan lapisan termoklin pada musim barat posisinya cukup dalam dan menguatkan bukti bahwa pada musim barat di Laut Banda tidak ditemukan indikator upwelling (Rochmady 2015; Wijaya et al, 2018). Wyrtki (1961) menyebutkan pada musim barat (Desember-Februari) di Laut Banda justru terjadi downwelling akibat masukan air dari Laut Jawa dan Laut Flores, dan sedikitnya massa air yang mengalir ke Samudera Pasifik. Fluktuasi terbesar salinitas berada di kedalaman $50 \mathrm{~m}$ (rerata 34.27 psu dan simpangan baku $0.578 \mathrm{psu}$ ). Kandungan oksigen terlarut (DO) semakin menurun dengan bertambahnya kedalaman (permukaan sampai kedalaman sekitar $200 \mathrm{~m}$, simpangan baku terbesar di kedalaman $10 \mathrm{~m}$ ). Rerata klorofil maksimum berada di kedalaman $67.53 \mathrm{~m}$.

Tabel 1. Deskripsi statistik data CTD

Table 1. Description of CTD data statistics

\begin{tabular}{ll|lllll}
\hline No. & \multicolumn{1}{|c|}{ Parameter } & Unit & Min & Rerata & Max & Stdev \\
\hline 1 & Temperature at $5 \mathrm{~m}$ & ${ }^{\circ} \mathrm{C}$ & 28.74 & 29.74 & 30.38 & 0.394 \\
2 & Temperature at $50 \mathrm{~m}$ & ${ }^{\circ} \mathrm{C}$ & 27.88 & 29.24 & 29.91 & 0.001 \\
3 & Temperature at $125 \mathrm{~m}$ & ${ }^{\circ} \mathrm{C}$ & 18.54 & 20.40 & 22.20 & 1.085 \\
4 & Temperature at $200 \mathrm{~m}$ & ${ }^{\circ} \mathrm{C}$ & 13.66 & 15.01 & 16.71 & 0.748 \\
5 & Temperature at $500 \mathrm{~m}$ & ${ }^{\circ} \mathrm{C}$ & 7.74 & 8.7 & 8.12 & 0.260 \\
6 & Salinity at $5 \mathrm{~m}$ & $\mathrm{PSU}$ & 33.45 & 33.99 & 34.44 & 0.331 \\
7 & Salinity at $50 \mathrm{~m}$ & $\mathrm{PSU}$ & 33.94 & 34.27 & 34.50 & 0.578 \\
8 & Salinity at $125 \mathrm{~m}$ & $\mathrm{PSU}$ & 34.45 & 34.51 & 34.54 & 0.003 \\
9 & Salinity at $200 \mathrm{~m}$ & $\mathrm{PSU}$ & 34.52 & 34.55 & 34.58 & 0.018 \\
10 & Salinity at $500 \mathrm{~m}$ & $\mathrm{PSU}$ & 34.52 & 34.57 & 34.63 & 0.020 \\
11 & Dissolved Oxygen at $5 \mathrm{~m}$ & $\mathrm{mg} / 1$ & 4.83 & 6.81 & 9.41 & 1.378 \\
12 & Dissolved Oxygen at $50 \mathrm{~m}$ & $\mathrm{mg} / 1$ & 5.39 & 6.16 & 6.01 & 0.153 \\
13 & Dissolved Oxygen at $125 \mathrm{~m}$ & $\mathrm{mg} / 1$ & 3.91 & 4.14 & 4.38 & 0.125 \\
14 & Dissolved Oxygen at $200 \mathrm{~m}$ & $\mathrm{mg} / 1$ & 3.39 & 3.65 & 3.88 & 0.119 \\
15 & Dissolved Oxygen at $500 \mathrm{~m}$ & $\mathrm{mg} / 1$ & 0.04 & 0.04 & 0.05 & 0.154 \\
16 & Depth of Chl-a max & $\mathrm{m}$ & 45 & 67.53 & 88 & - \\
\hline
\end{tabular}

\section{Struktur dan Jenis Massa Air}

Struktur massa air yang ditunjukkan grafik hubungan suhu-salinitas (T-S) dan suhu-oksigen (Gambar 2) dicirikan oleh massa air hangat dan relatif salin di dekat permukaan (isopiknal <21). Dari lapisan termoklin hingga $500 \mathrm{~m}$ pada bulan Februari ini tidak ditemukan ciri massa air bersalinitas tinggi yang berasal dari Pasifik Utara, salinitas relatif homogen sekitar 34.5 psu. Kondisi ini sesuai dengan temuan Wijaya et al., (2018) bahwa distribusi vertikal salinitas di Laut Banda pada periode monsun barat lebih tinggi di atas 34 PSU sampai pada kedalaman $>200 \mathrm{~m}$. Kandungan oksigen maksimum berada pada isopiknal $<5$.Kandungan khlorofil maksimum umumnya berada di sekitar isopycnal 22. Gordon dan Field (1994) menemukan massa air air Pasifik Utara sub tropik dan massa air Pasifik Utara intermediate di Laut Banda bagian barat pada bulan Desember, dengan ciri maksimum di sekitar $110 \mathrm{dbar}\left(20^{\circ} \mathrm{C}\right)$ dan salinitas minimum di sekitar $300 \mathrm{dbar}\left(10^{\circ} \mathrm{C}\right)$.

\section{Sebaran Horizontal}

Sebaran horizontal (Gambar 3), menunjukkan nilai sebaran suhu permukaan laut (SPL) berkisar antara $28,07-30,40{ }^{\circ} \mathrm{C}$ (rata-rata $29.64{ }^{\circ} \mathrm{C}$ ) dengan pola nilai sebaran yang semakin tinggi ke arah daratan. Hal ini umum terjadi karena daratan lebih mudah menyerap panas matahari, sedangkan laut tidak mudah mengubah suhu bila suhu lingkungan tidak berubah. Sementara daerah lepas pantai, SPL cenderung lebih rendah dan stabil. Nilai SPL minimum $\left(28.07{ }^{\circ} \mathrm{C}\right)$ terdapat pada stasiun 17 di bagian tengah perairan dan maksimum $\left(30.48^{\circ} \mathrm{C}\right)$ pada stasiun 6 yang berada dekat daratan. Nilai kisaran pada bulan Februari ini relatif sama dengan yang dilaporkan Gordon \& Ilahude (1994) pada musim barat berkisar $29.6^{\circ} \mathrm{C}-30.3^{\circ} \mathrm{C}$. Juga relatif sama dengan pengukuran sensor satelit seperti dilaporkan Hariati et al., (2010) pada Februari berkisar $29,5-30,5^{\circ} \mathrm{C}$ dan menurut Putra et al, (2017) SPL pada bulan Februari 2016 merupakan yang terendah yakni $27,9{ }^{\circ} \mathrm{C}$. Sementara rerata pengukuran musim barat umumnya $>29^{\circ} \mathrm{C}$ (Wijaya et al., 2018). 

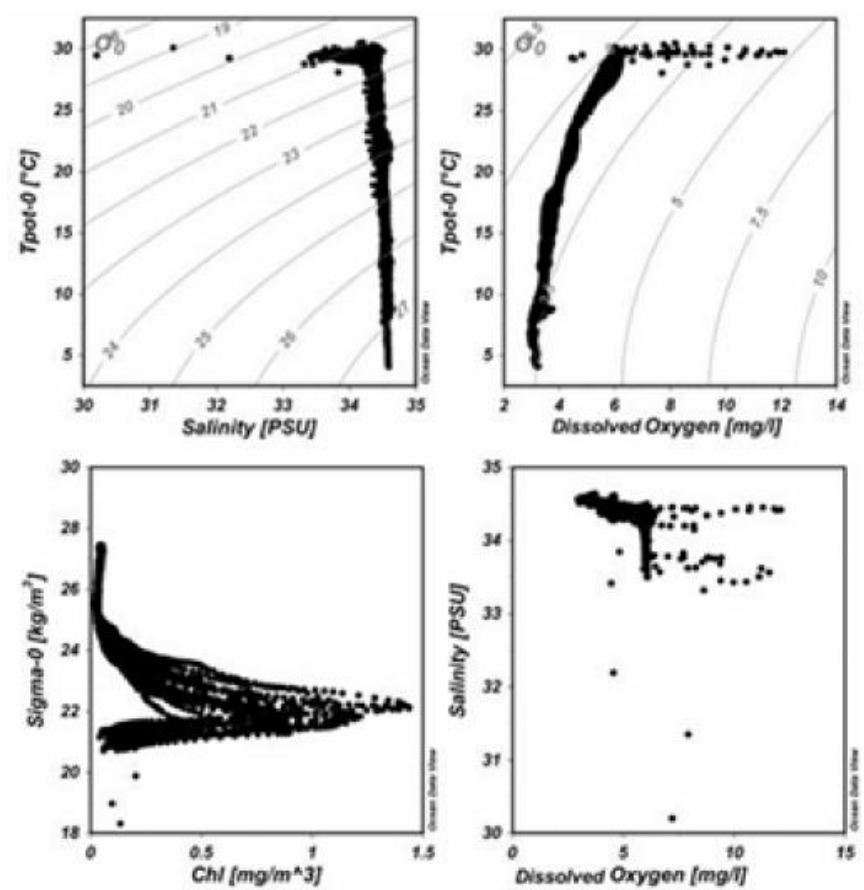

Gambar 2. Scatter plot diagram Temperature-Salinity (TS), Temperature-Dissolved Oxygen (TO), DensitasChlorofil, (DC) dan Salinity-Dissolved Oxygen (S0).

Figure 2. Scatter plot diagram of Temperature-Salinity (TS), Temperature-Dissolved Oxygen (TO), DensityChlorophyll, (DC) and Salinity-Dissolved Oxygen (SO).

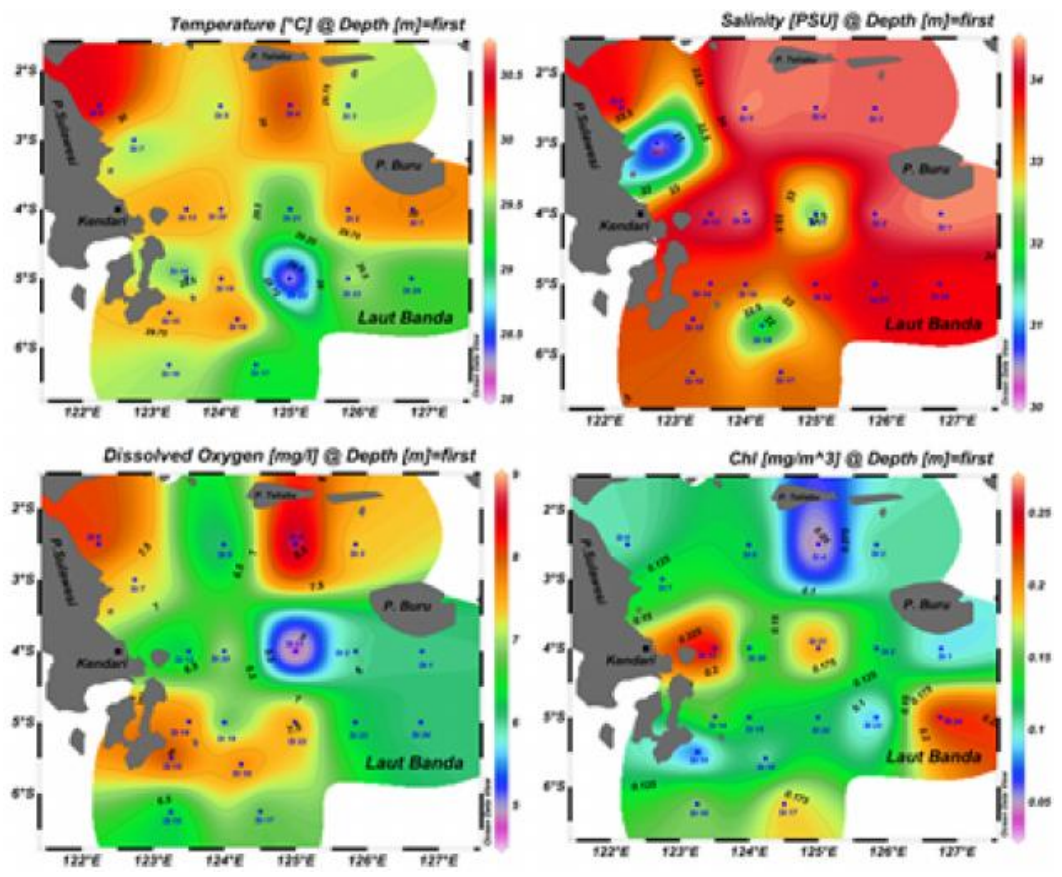

Gambar 3. Sebaran Horizontal Permukaan (5 m).

Figure 3. Surface Horizontal Distribution (5 m).

Sebaran salinitas permukaan berkisar antara 30.2034,45 PSU (rerata 33.58 PSU) dengan pola lebih rendah pada stasiun yang berada di dekat daratan. Salinitas permukaan paling rendah ditemukan di stasiun 7 dekat pantai Sulawesi Tenggara dan salinitas tinggi di stasiun 15 lepas pantai (ke tengah Laut Banda). Nilai sebaran rata-rata kandungan Oksigen terlarut (DO) sebesar 6.88 $\mathrm{mg} / \mathrm{l}$ dengan kandungan DO tertinggi $(8.77 \mathrm{mg} / \mathrm{l})$ 
terdapat pada stasiun 4 yang berlokasi di selatan Pulau Taliabo. Kandungan DO tinggi juga ditemukan di stasiun 6 (Teluk Tolo); serta stasiun-stasiun dekat Pulau Buton dan kepulauan Wakatobi (stasiun 9-14). Nilai DO minimum (4.55 mg/l) pada stasiun 16. Nilai sebaran klorofil-a permukaan rata-rata $0.13 \mathrm{mg} / \mathrm{m}^{3}$. Sebaran klorofil permukaan tertinggi $\left(0.26 \mathrm{mg} / \mathrm{m}^{3}\right)$ ditemukan pada stasiun 8 dan stasiun 19 dan terendah $(0.04 \mathrm{mg} /$ $\mathrm{m}^{3}$ ) pada stasiun 4 (perairan Taliabo). Sebagai pembanding, Nontji (2005) menyatakan bahwa konsentrasi klorofil-a di perairan Indonesia rata-rata $0,19(\mathrm{mg} /)$ selama musim barat.
Nilai sebaran suhu, salinitas, DO dan klorofil berdasarkan kedalaman 50m, $125 \mathrm{~m}$, dan $200 \mathrm{~m}$ ditampilkan pada Tabel 2 dan pola sebarannya pada Gambar 4. Pada kedalaman 50m pola sebaran parameter oseanografi sama dengan lapisan permukan. Massa air dengan suhu yang lebih hangat berada dekat daratan Sulawesi Tenggara dan Kepulauan Wakatobi dan suhu lebih rendah ditemukan di perairan selatan P. Taliabo. Pola sebaran salinitas dan DO umumnya tinggi pada bagian utara perairan dan lebih rendah di stasiun bagian selatan. Sebaran khlorofil-a menunjukkan sebaran minimum berada pada stasiun-stasiun di bagian tengah dan klorofil tertinggi di temukan di selatan P. Taliabo.

Tabel 2. Nilai sebaran suhu, salinitas, DO dan klorofil pada kedalaman 50, 125 dan 200m

Table 2. Value of temperature distribution, salinity, DO and chlorophyll at depths of 50, 125 and $200 \mathrm{~m}$

\begin{tabular}{c|cc|cc|cc|cc}
\hline \multirow{2}{*}{$\begin{array}{c}\text { Strata } \\
\text { Kedalaman }\end{array}$} & \multicolumn{2}{|c|}{ Suhu $\left({ }^{0} \mathrm{C}\right)$} & \multicolumn{2}{c|}{ Salinitas (psu) } & \multicolumn{2}{c|}{ DO (mg/l) } & \multicolumn{2}{c}{ Klorofil $\left(\mathrm{m}^{3}\right)$} \\
\cline { 2 - 9 }$(\mathrm{m})$ & Kisaran & Rerata & Kisaran & Rerata & Kisaran & Rerata & \multirow{2}{*}{ Kisaran } & Rerata \\
\hline 50 & $27,87-29,91$ & 29,24 & $33,94-34,50$ & 34,27 & $5,39-6,16$ & 6,01 & $0,18-1,24$ & 0,71 \\
125 & $18,54-22,20$ & 20,37 & $34,51-34,51$ & 34,52 & $3,92-4,38$ & 4,15 & $0,04-0,19$ & 0,12 \\
200 & $13,66-16,71$ & 15,19 & $34,52-34,57$ & 34,54 & $3,39-3,88$ & 3,64 & $0,02-0,03$ & 0,03 \\
\hline
\end{tabular}
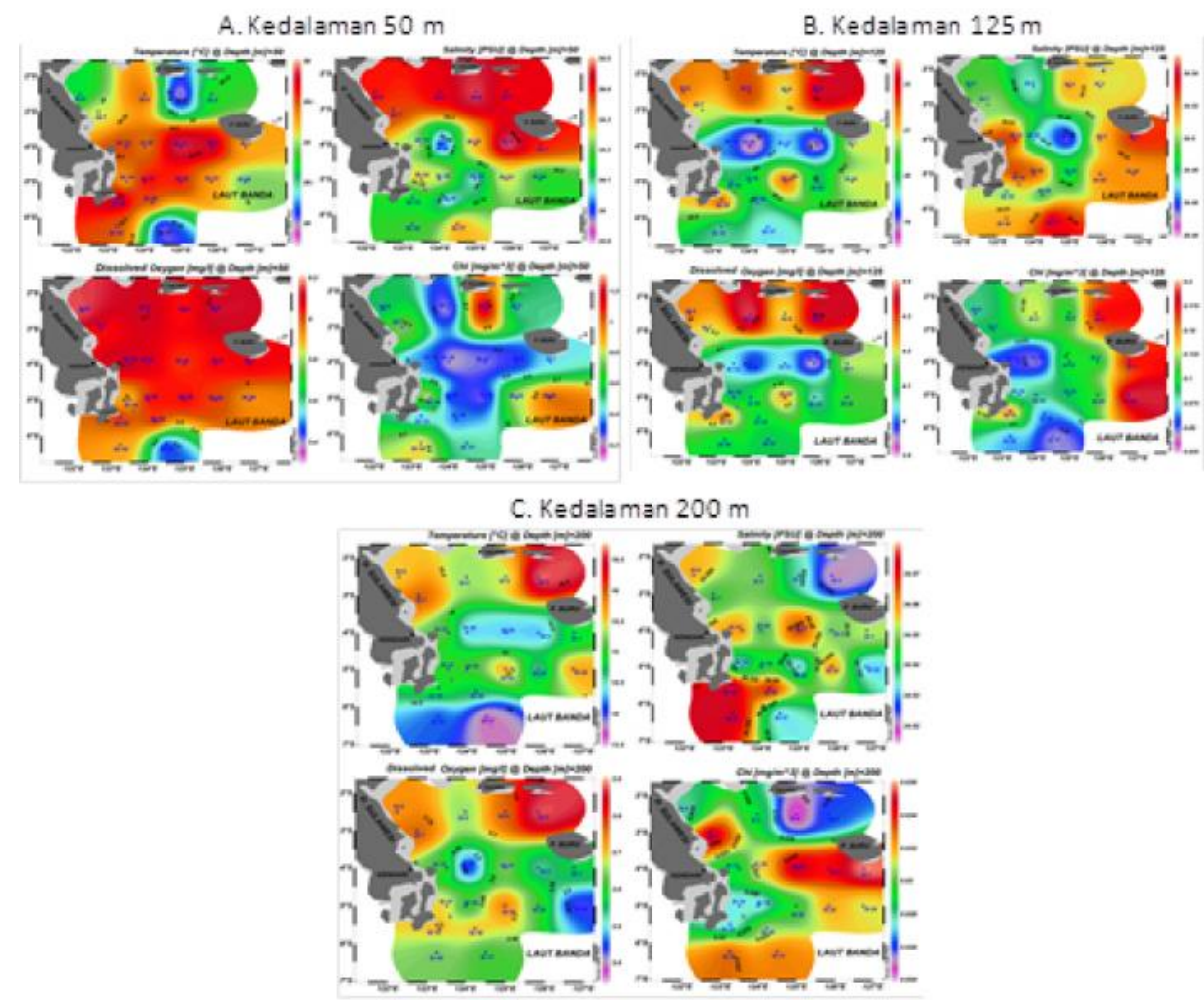

Gambar 4. Sebaran horizontal suhu kedalaman: A (50m); B (125m); dan C (200 m).

Figure 4. Horizontal distribution of depth temperature: A (50m); B (125m); and C (200 m). 
Pada kedalam $125 \mathrm{~m}$, nilai sebaran suhu menurun drastis, mengindikasikan kedalaman 125m merupakan bagian dari lapisan termoklin, dengan nilai sebaran berkisar $18.54-22.20^{\circ} \mathrm{C}$. Nilai sebaran salinitas sedikit lebih tinggi dibanding kedalaman $50 \mathrm{~m}$ dengan salinitas tinggi di bagian timur perairan. Sebaran DO dan klorofil juga menurun drastis. Nilai sebaran DO hampir setengah dari nilai sebaran di kedalaman $50 \mathrm{~m}$ dengan nilai sebaran tinggi di bagian utara perairan. Nilai sebaran klorofil jauh lebih rendah dibanding kedalaman $50 \mathrm{~m}$ dengan nilai sebaran lebih tinggi di bagian timur perairan. Massa air dengan nilai sebaran klorofil rendah di temukan di sekitar Kepulauan Wakatobi dan timur perairan Kendari (sekitar P. Wowoni).

Pada kedalaman $200 \mathrm{~m}$, nilai sebaran suhu menurun drastis $\left(13.66-16.71^{\circ} \mathrm{C}\right)$ sementara salinitas dan DO relatif sama dengan kedalaman $125 \mathrm{~m}$. Nilai sebaran klorofil pada kedalaman ini juga jauh lebih rendah. Suhu rendah berada di bagian selatan perairan (Wakatobi) dan suhu tinggi di bagian timur laut perairan (utara P. Buru). Sebaliknya, di lokasi perairan dengan suhu rendah tersebut, nilai sebaran salinitasnya lebih tinggi, diduga merupakan massa air dalam. Sementara di lokasi suhu tinggi, massa airnya memiliki salinitas rendah dan nilai sebaran klorofil juga rendah, namun memiliki nilai sebaran DO yang tinggi.

\section{Sebaran Melintang}

Sebaran melintang (cross-section: timur-barat) suhu, salinitas, khlorofil dan oksigen terlarut (DO) di sepanjang lintasan (Gambar 7), menunjukkan ciri fluktuasi ketebalan lapisan tercampur (mixed layer), dimana batas bawah lapisan tercampur ditandai oleh isotherm $27.5^{\circ} \mathrm{C}$. Ketebalan lapisan tercampur pada stasiun 13-19 terlihat lebih dalam. Pada kedalaman 75$150 \mathrm{~m}$ terjadi fluktuasi penurunan suhu yang dilihat dari garis isotherm $17.5{ }^{\circ} \mathrm{C}$ hingga $27.5{ }^{\circ} \mathrm{C}$ yang mengindikasikan zona termoklin. Zona termoklin yang terlihat pada musim barat ini karakteristiknya ternyata berbeda dengan termoklin saat terjadinya El-Nino di Laut Banda, yang teridentifikasi sebagai lapisan isoterm $21^{\circ} \mathrm{C}$ (Bray et al. 1996; Gordon et al. 2000). Lebih lanjut, Bray et al. (1996) menjelaskan bahwa lapisan termoklin wilayah Indonesia lebih dangkal yaitu pada lapisan 10-20 m, daripada kedalaman lapisan termoklin di Samudera Pasifik dan Hindia yang diidentifikasi dengan isoterm $20^{\circ} \mathrm{C}$. Dengan demikian berarti, lapisan termoklin Laut Banda yang terindentifikasi pada musim barat ini posisinya lebih dalam.

Garis Semakin tipis jarak garis isotherm tersebut menandakan semakin kuatnya gradien penurunan suhu (stasiun 13). Salinitas di lapisan tercampur umumnya berada pada kisaran 34 psu. Salinitas paling rendah
(30.20 psu) ditemukan di stasiun 7, tetapi hanya pada permukaan saja. Setelah kedalaman $50 \mathrm{~m}$ nilai salinitas tidak banyak berubah hingga kedalaman $500 \mathrm{~m}$ yang berada pada kisaran 34.5 psu. Sebaran melintang DO, menunjukkan nilai sebaran tertinggi $(6 \mathrm{mg} / \mathrm{l})$ ditemukan pada stasiun 14-17 dan masih terdapat hingga kedalaman $80 \mathrm{~m}$. Pada kedalaman $200 \mathrm{~m}-500$ $\mathrm{m}$ nilai DO cenderung lebih tinngi pada stasiun 3-5. Khusus pada stasiun 4 dari kedalaman $470-500 \mathrm{~m}$ nilai DO terlihat sedikit meningkat, hal ini diduga adanya pengaruh dari massa air di bawahnya. Nilai klorofil tinggi mulai terdapat pada kedalaman 45-88 $\mathrm{m}$ dengan konsentrasi tertinggi pada kedalaman $60-70 \mathrm{~m}$ di stasiun 5 (kisaran $1.30-1.44 \mathrm{mg} / \mathrm{m}^{3}$ ).

\section{Sebaran Vertikal}

Profil menegak parameter oseanografi untuk seluruh stasiun (Gambar 8) menunjukkan suhu yang hangat di dekat permukaan, dengan nilai kisaran bervariasi antara $28.07-30.48{ }^{\circ} \mathrm{C}$. Di kedalaman 500 $\mathrm{m}$, kisaran nilai sebaran suhu $7.74-8.70{ }^{\circ} \mathrm{C}$. Variasi terbesar suhu ditemukan pada lapisan termoklin dicirikan dari profil yang menurun secara drastis mulai kedalaman $50 \mathrm{~m}$ hingga kedalaman $150-200 \mathrm{~m}$. Sebagai pembanding, lapisan termoklin di Laut Flores berada sedikit lebih dalam yaitu pada kedalaman $60-250 \mathrm{~m}$ (Tubalawoni et al, 2012). Prasetyo et al, (2019) menyebutkan kondisi profil suhu laut vertikal Laut Banda pada saat terjadi El-Nino dipengaruhi oleh tipe El-Nino yaitu Eastern-Pacific (EP) dan Central-Pacific (CP) El Niño. Penurunan maksimum suhu laut saat EP El Niño mencapai $-1.5^{\circ} \mathrm{C}$ sedangkan penurunan maksimum akibat CP El Niño mencapai $-0.9^{\circ} \mathrm{C}$. Lebih lanjut dijelaskan bahwa penurunan suhu laut maksimum saat EP El Niño terjadi pada kedalaman 90-120 m, sedangkan saat CP El Niño terjadi lebih dalam yaitu pada kedalaman 140-160 m di Laut Banda Barat dan 160-200 m di Laut Banda Timur.

Variasi terbesar salinitas berada di dekat permukaan karena ada salinitas relatif rendah di stasiun yang dekat dengan daratan, sementara di bagian dalam setelah $100 \mathrm{~m}$ hampir tidak ada variasi signifikan seperti yang terlihat dari grafik yang nyaris sejajar pada nilai sekitar 34.50-34.59 psu. Hal ini mengindikasikan keberadaan massa air bersalinitas tinggi dengan range sempit. Wijaya et al, (2018) menyebutkan distribusi vertikal salinitas di Laut Banda pada periode monsun barat lebih tinggi di atas 34 PSU sampai pada kedalaman $>200 \mathrm{~m}$. sedangkan untuk periode monsun timur lebih rendah 33 PSU sampai kedalaman $<50 \mathrm{~m}$, serta pada kedalaman $>$ $100 \mathrm{~m}$ berkisar antara 34-34,5 PSU. Sebaran vertikal DO menunjukkan nilai maksimum terdapat pada kedalaman $10 \mathrm{~m}$ dan semakin berkurang dengan 

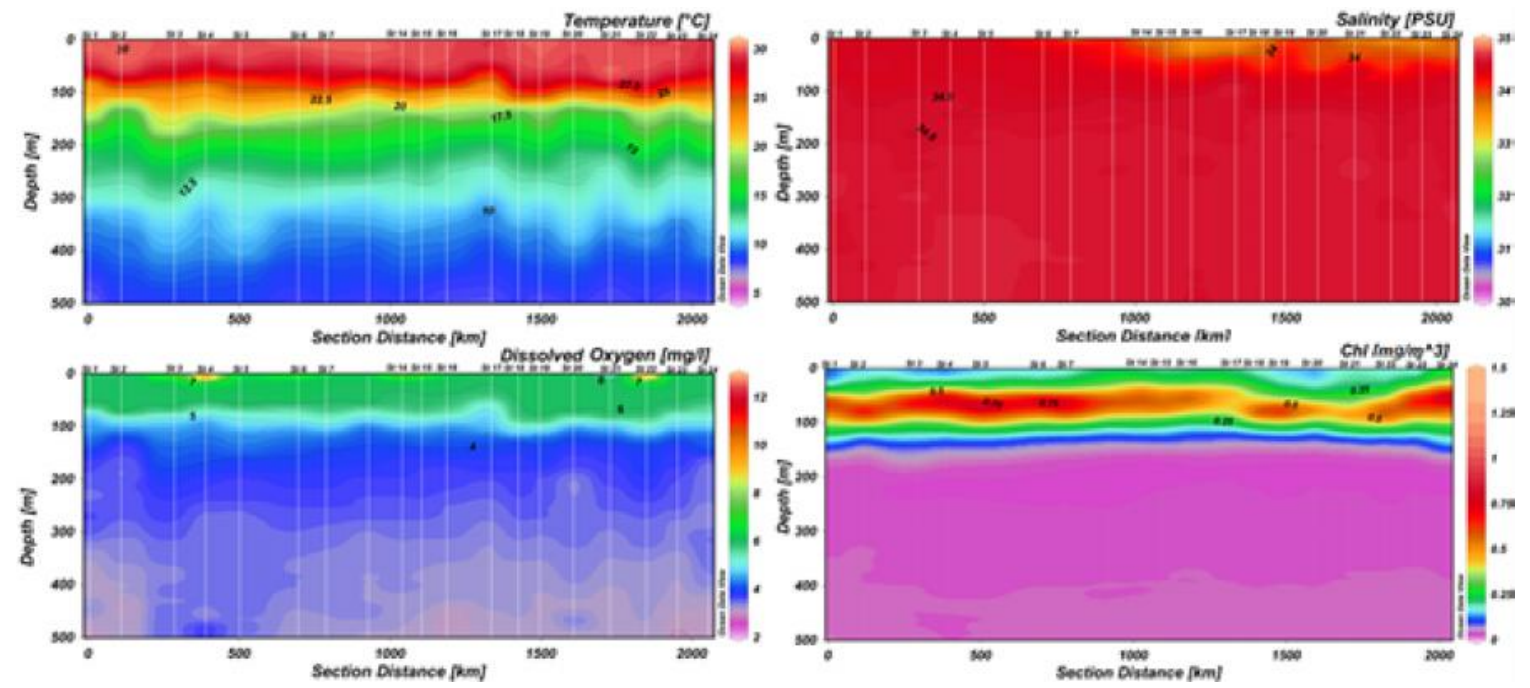

Gambar 5. Sebaran melintang sepanjang lintasan stasiun.

Figure 5. Transverse distribution along the station trajectory.
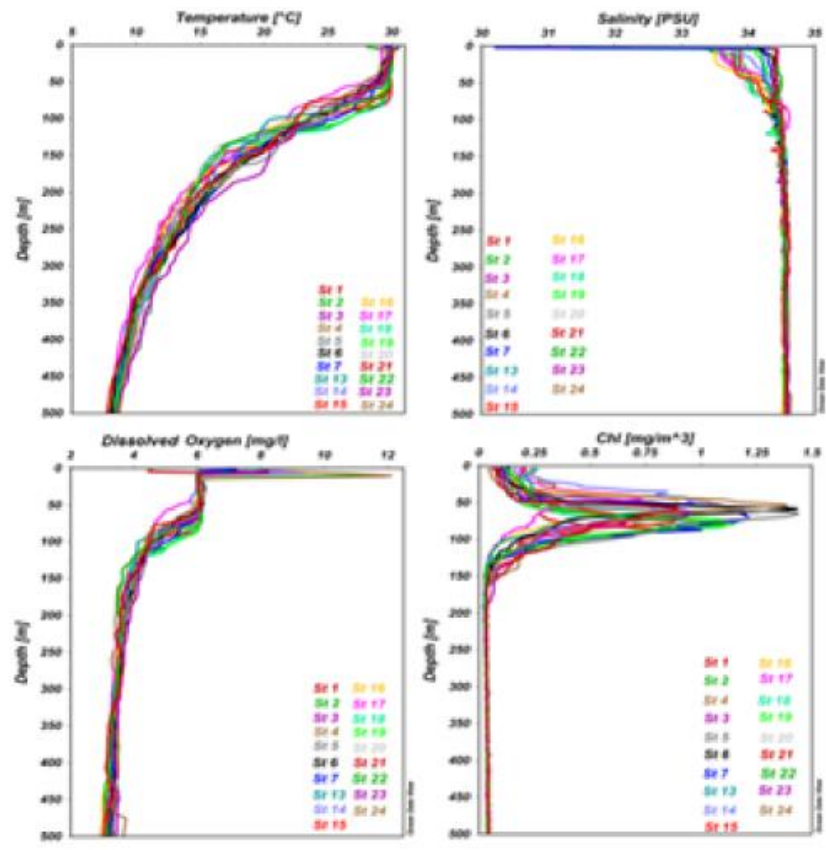

Gambar 6. Sebaran vertikal parameter oseanografi semua stasiun.

Figure 6. Vertical distribution of oceanographic parameters of all stations.

bertambahnya kedalaman. Sementara grafik vertikal khlorofil menunjukkan peningkatan pada kedalaman 50 dengan puncak di sekitar kedalaman $60 \mathrm{~m}$ dan kembali menurun seiring bertambahnya kedalaman.

\section{Arus Permukaan}

Arah dan kecepatan arus (Gambar 9) pada bulan Februari berkisar $0.4-0.8 \mathrm{~m} /$ detik dan nilai rata-rata kecepatannya (Tabel 3 dan Gambar 10). Daruwedho et al, (2016) menyebutkan kecepatan arus Laut Banda pada musim barat cenderung lemah hanya sekitar $0,4 \mathrm{~m} /$ detik. Arus umumnya cenderung bergerak ke arah selatan, terkait dengan periode akhir musim barat. Terdapat perbedaan pola arus pada stasiun 8 dan 12 arusnya cenderung mengarah ke timur; stasiun 11 cenderung mengarah ke utara; dan stasiun 14 cenderung mengarah ke timur laut. Kondisi ini sesuai dengan yang disebutkan Rizal et al, 2009 bahwa sirkulasi perairan Indonesia Timur pada monsun barat memperlihatkan aliran arus ke selatan dan membelok ke timur melewati Selat Flores dan Laut Banda, selanjutnya dibagian Laut Banda arus membelok ke 
utara dan timur laut menuju Samudera Pasifik dan Laut Arafuru.

Adapun pergerakan arus yang cenderung ke arah timur di stasiun 8 terjadi karena pembelokan daratan (Pulau Wowoni). Hal yang sama di stasiun 12 yang berada di sebelah tenggara Kepulauan Wakatobi sehingga arus yang bergerak kearah selatan dibelokan ke arah timur akibat bertemu daratan. Pada stasiun 11 dan 14 arus cenderung menuju ke arah utara diduga karena dorongan aliran massa air dari Laut Lawa dan Selat Makassar. Kecepatan arus tertinggi berada pada stasiun 17 dan yang terendah berada pada stasiun 6 . Stasiun 17 berlokasi di tengah tengah Laut Banda dan memiliki jarak paling jauh dari pulau sehingga fetch yang didapatkan lebih panjang, sementara stasiun 6 merupakan stasiun yang paling dekat dengan daratan sehingga fetch yang terbentuk kurang serta akibat terganggu daratan.

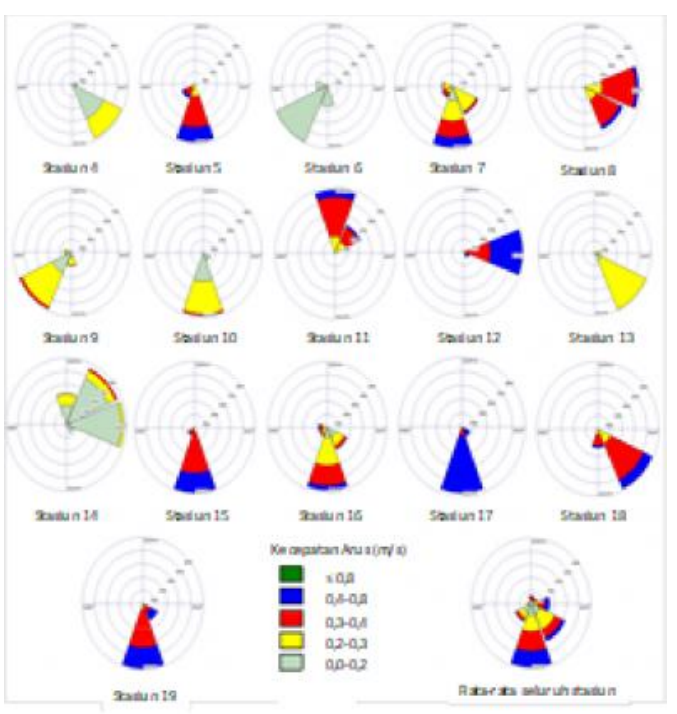

Gambar 7. Plot Arah dan Kecepatan Arus di Setiap Stasiun.

Figure 7. Plot of Flow Direction and Velocity at Each Station.

Tabel 3. Rata-rata arus dan kecepatan permukaan setiap stasiun

Table 3. Average current and surface velocity for each station

\begin{tabular}{ccccc}
\hline No. Sta. & Longitude & Latitude & $\begin{array}{c}\text { Arah } \\
\text { (Derajat) }\end{array}$ & Kecepatan (m/s) \\
\hline 1 & 1.267 .666 & -400.143 & N/A & N/A \\
2 & 1.258 .357 & -400.058 & N/A & N/A \\
3 & 1.258 .354 & -250.233 & 3.042 .451 .372 & 0.230741361 \\
4 & 1.249 .961 & -249.508 & 9.055 .606 .936 & 0.397943385 \\
5 & 1.239 .896 & -250.553 & 3.905 .449 .804 & 0.11914007 \\
6 & 1.222 .376 & -249.865 & 2.519 .178 .511 & 0.326310915 \\
7 & 1.227 .436 & -299.937 & 4.854 .821 .269 & 0.260019258 \\
8 & 1.235 .005 & -400.195 & 1.855 .123 .299 & 0.248786504 \\
9 & 123.502 & -499.045 & 1.952 .794 .252 & 0.378214202 \\
10 & 1.232 .548 & -549.843 & 271.781 .629 & 0.459924208 \\
11 & 1.232 .489 & -625.028 & 2.911 .517 .738 & 0.375477801 \\
12 & 1.245 .013 & -625.007 & 3.053 .353 .812 & 0.268819035 \\
13 & 1.242 .334 & -558.953 & 2.385 .681 .863 & 0.172848873 \\
14 & 1.239 .988 & -500.265 & 498.652 .968 & 0.419999658 \\
15 & 1.239 .975 & -399.805 & 2.230 .932 .047 & 0.314924119 \\
16 & 1.249 .971 & -399.907 & 2.580 .522 .904 & 0.535056366 \\
17 & 1.249 .895 & -499.907 & 3.305 .059 .411 & 0.389973015 \\
18 & 1.258 .329 & -499.955 & 3.313 .675 .169 & 0.429919677 \\
19 & 126.75 & -499.955 & & \\
\hline
\end{tabular}




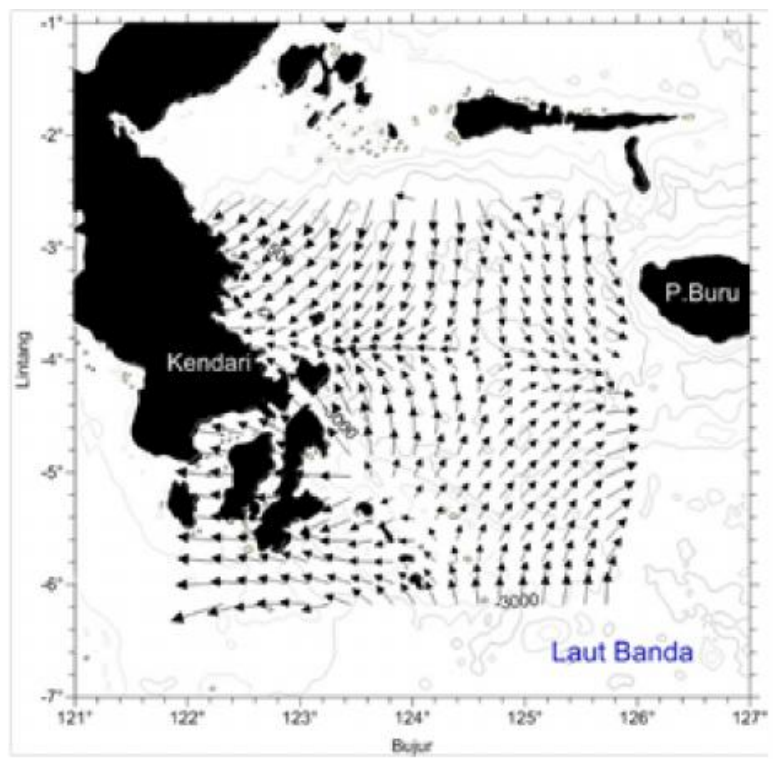

Gambar 8. Pola sebaran rerata arus permukaan.

Figure 8. The distribution pattern of the mean surface current.

\section{KESIMPULAN}

Pada musim barat, lapisan tercampur (mixed layer) cukup tebal ditemukan sampai kedalaman $70 \mathrm{~m}$ dan lapisan terkmoklin berada cukup dalam $>100 \mathrm{~m}$ dengan fluktuasi terbesar suhu berada pada kedalaman 125 $\mathrm{m}$. Tidak ditemukan massa air yang berasal dari Pasifik Utara/Selatan, menandakan tidak adanya massa air Arlindo di lapisan dalam. Suhu lapisan permukaan cenderung lebih hangat dan salinitas lebih rendah di bagian pesisir. Pada bulan Februari, masih terdeteksi pengaruh arus musim barat dari Laut Flores yang menyebabkan massa air laut Banda bagian selatan arusnya bergerak ke utara dan timur laut. Nilai sebaran rerata klorofil yang rendah $\left(0.13 \mathrm{mg} / \mathrm{m}^{3}\right)$, menununjukkan kesuburan Laut Banda bagian barat lebih rendah dibanding perairan Indonesia pada umumnya.

\section{UCAPAN TERIMA KASIH}

Tulisan ini merupakan kontribusi dari Kegiatan Penelitian Karakteristik Biologi Perikanan serta Habitat Sumber Daya dan Potensi Produksi Sumber Daya Ikan di WPP 714 (Teluk Tolo dan Laut Banda), Balai Riset Perikanan Laut (BRPL) TA 2016. Penulis mengucapkan terima kasih kepada segenap pihak yang telah membantu dalam pengambilan data saat cruise K/R Baruna Jaya VII.

\section{DAFTAR PUSTAKA}

Birowo, S. (1984). Ekspedisi ilmiah kelautan Snellius II, Indonesia-Belanda (Juli 1984-Juli 1985). Berita Ilmu Pengetahuan dan Teknologi -LIPI 28: 23-42.
Bray, N. A., Hautala, S., Chong, J., \& Pariwono, J. (1996). Large-Scale Sea Level, Thermocline, and Wind Variation in the Indonesian through Flow Region. Journal Geophys Research 101:1223912254.

Daruwedho, H., Sasmito, B., \& Fauzi, J.A. (2016). Analisis Pola Arus Laut Permukaan Perairan Indonesia dengan Menggunakan Satelit Altimetri Jason-2 Tahun 2010-2014, 5(2), 145-158.

Gordon, A. L., Fielde, A., \& Illahude, A. G. (1994). Thermocline of the Flores and Banda Seas. Journal of Geophysical Research. 99: 18, 235-242.

Gordon, A. L., Ffield, A., Vranes, K., Garzoli, S. L., \& Susanto. (2000). Temperature Variability within Makassar Strait. J. Geophys. Res. Let. 27(2):237240.

Hariati, T., Amri, K., \& Chodriyah, U. (2010). Fluktuasi Hasil Tangkapan Ikan Layang (Decapterus Spp.) di Perairan Kendari dan Sekitarnya serta Kaitannya dengan Sebaran Suhu Permukaan Laut, Salinitas, dan Klorofil-a Permukaan. Jurnal Penelitian Perikanan Indonesia, 16(2), 135-146.

Nontji, A. (2005). Laut Nusantara. Djambatan. Jakarta. Prasetyo, B., Pusparini, N., \& Radjawanne, I.M. (2019). Profil Vertikal Suhu Laut Banda Terkait Kejadian El Niño di Pasifik Timur dan Pasifik Tengah. Jurnal Oseanologi dan Limnologi di Indonesia 2019, $4(1), 15-26$.

Putra, I.I., Sukmono, A., \& Wijaya, A.P. (2017). Analisa Pola Sebaran Area Upwelling Menggunakan Parameter Suhu Permukaan Laut, Klorofil-a, Angin dan Arus secara Temporal Tahun 2003-2016 (Studi 
Kasus: Laut Banda). Jurnal Geodesi, 6(4), 157-168.

Rizal, S., Setiawan, I., Muhammad, Iskandar, T., \& Wahid, M.A. (2009). Simulasi Pola Arus Baroklinik di Perairan Indonesia Timur dengan Model Numerik Tiga-dimensi. Jurnal Matematika dan Sains, 14(4), 113-119.

Rochmady. (2015). Analisis Parameter Oseanografi Melalui Pendekatan Sistem Informasi Manajemen Berbasis Web (Sebaran Suhu Permukaan Laut, Klorofil-a dan Tinggi Permukaan Laut). Jurnal Ilmiah Agribisnis dan Perikanan (agrikan UMMU-Ternate), 8(1), 1-7.

Sulaiman. (2000). Banda Sea turbulence (Indonesia Through Flow Microstructure Introduction study). Badan Penerapan dan Pengkajian Teknologi. Jakarta.

Suyarso. (1999). Lingkungan Fisik Kawasan Laut Banda dalam Suyarso (ed). Atlas Oseanologi di Indonesia. Lembaga Oseanologi Nasional LIPI. Jakarta. hal. 15.
Tapilatu, Y.H. (2016). Profil Oseanografi Biologi Laut Banda: Sebuah Tinjauan Kritis. Jurnal OmniAkuatika, 12(2), 58- 66.

Tubalawony, S., Kusmanto, E., \& Muhadjirin. (2012). Suhu dan Salinitas Permukaan Merupakan Indikator Upwelling Sebagai Respon Terhadap Angin Muson Tenggara di Perairan Bagian Utara Laut Sawu. Ilmu Kelautan, 17(4), 226-239.

Wijaya, A., Priyono, B., \& Mahdalena, N.A. (2018). Karakteristik Spasial Temporal Kondisi Oseanografi Laut Banda dan Hubungannya dengan Potensi Sumberdaya Perikanan. Journal of Fisheries and Marine Science. 2(2), 75-85.

Wyrtki, K. (1958). The water exchange between the Pacific and the Indian Ocean in relation to upwelling processes. Proc. 9th Pac. Sci.Congr. 16:61-66.

Wyrtki, K. (1961). Physical Oceanography of the SouthEast Asian Waters, Naga Report 2: 1-195. 